\title{
Thyroid hormone function in the rat testis
}

\author{
Ying Gao ${ }^{1}$, Will M. Lee ${ }^{2}$ and C. Yan Cheng ${ }^{1}{ }^{*}$ \\ ${ }^{1}$ Center for Biomedical Research, Population Council, New York, NY, USA \\ ${ }^{2}$ School of Biological Sciences, The University of Hong Kong, Hong Kong, China
}

Edited by:

Fátima Regina Mena Barreto Silva,

Universidade Federal de Santa

Catarina, Brazil

Reviewed by:

Takashi Yoshimura, Nagoya University, Japan

Takayoshi Ubuka, Waseda University, Japan

*Correspondence:

C. Yan Cheng, The Mary M. Wohlford

Laboratory for Male Contraceptive

Research, Center for Biomedical

Research, Population Council, 1230

York Avenue, New York, NY 10065,

USA

e-mail:y-cheng@popcbr.

rockefeller.edu;

ccheng@rockefeller.edu
Thyroid hormones are emerging regulators of testicular function since Sertoli, germ, and Leydig cells are found to express thyroid hormone receptors (TRs). These testicular cells also express deiodinases, which are capable of converting the pro-hormoneT4 to the active thyroid hormone T3, or inactivating T3 or T4 to a non-biologically active form. Furthermore, thyroid hormone transporters are also found in the testis. Thus, the testis is equipped with the transporters and the enzymes necessary to maintain the optimal level of thyroid hormone in the seminiferous epithelium, as well as the specific TRs to execute thyroid hormone action in response to different stages of the epithelial cycle of spermatogenesis. Studies using genetic models and/or goitrogens (e.g., propylthiouracil) have illustrated a tight physiological relationship between thyroid hormone and testicular function, in particular, Sertoli cell differentiation status, mitotic activity, gap junction function, and blood-testis barrier assembly. These findings are briefly summarized and discussed herein.

Keywords: testis, thyroid hormones, spermatogenesis, gap junction, blood-testis barrier, seminiferous epithelial cycle

\section{INTRODUCTION}

Thyroid hormones play a crucial role in regulating development, differentiation, and metabolism in multiple mammalian tissues. Testis was regarded as a thyroid hormone unresponsive organ for many years. In the past two decades, however, mounting evidence has emerged demonstrating the presence of functional thyroid hormone receptors (TRs) in the testis $(1,2)$. These findings illustrate that thyroid hormones likely play an important role in testis function. Studies have demonstrated that thyroid hormones most notably T3 (3,5,3'-tri-iodothyronine) regulates Sertoli cell proliferation and differentiation during testis development including the assembly of the blood-testis barrier (BTB) (3-5). Moreover, it also induces Leydig cell differentiation and stimulates steroidogenesis in the rat testis (6). Several idothyronine deiodinases and thyroid hormone transporters have been identified in the testis (7-10), illustrating that these enzymes and transporters necessary to maintain the homeostasis of thyroid hormone are present in the testis. It is generally accepted that thyroid hormone acts as an important regulator in testis development. However, few studies focused on the role of thyroid hormone in regulating spermatogenesis in adult testis. Studies in recent years have suggested that altered thyroid status in adult males is associated with abnormal spermatogenesis, reducing sexual activity and impeding fertility (11-15), illustrating the crucial relationship between thyroid hormones and maturation status of Sertoli cells. In fact, TR $\alpha 1$ is a reliable marker of Sertoli cell maturation because its expression is considerably down-regulated in adult testes, and continual expression of TR $\alpha 1$ illustrates delayed Sertoli cell maturation in adult mice $(16,17)$. There are also reports in recent years that thyroid hormone is crucial to maintain gap junction (GJ) and BTB function, as well as BTB maturation during postnatal development. Our goal in this mini-review is to focus on the role of thyroid hormone and junction dynamics, in particular, the BTB function during spermatogenesis, providing an update on the current status of research in this area. We also highlight research areas that deserve attention in future studies. We first provide a brief outline regarding the role of thyroid hormone in testis development and testicular function since this information is closely related to the emerging field in which thyroid is a major player in junction dynamics during spermatogenesis.

\section{THYROID HORMONE ACTION}

Thyroxin $\left(3,5,3^{\prime}, 5^{\prime}\right.$-tetraiodothyronine, T4) is the major form of thyroid hormones released by the thyroid gland into the systemic circulation. Thyroxin, however, is a pro-hormone, which must be converted to tri-iodothyronine (3,5,3'-tri-iodothyronine, T3), which takes place primarily in the liver and kidney. T3 is the bioactive form of thyroid hormone that has high affinity for nuclear TRs $(18,19)$. A small amount of T3 and reverse T3 (rT3), however, is also produced by the thyroid gland (20). T3 mediates its effects via genomic and also non-genomic pathways. For the classical genomic pathway, T3 mediates its effects by TRs. In the nucleus, TRs usually forms heterodimers with retinoid $\mathrm{X}$ receptor (RXR), and this complex further binds to thyroid response elements (TRE) in the promoter region of a target gene to regulate gene transcription (21). In addition, thyroid hormone also regulates the release of thyrotrophin-releasing hormone (TRH) by the hypothalamus and of thyroid-stimulating hormone (TSH) by the pituitary gland (21) to serve as a feedback loop in the hypothalamic-pituitary-thyroid axis to maintain the physiological level of thyroid hormone in the systemic circulation. In contrast to the genomic pathway, which has a relatively long response time, ranging from hours to days, non-genomic pathways have short latency and are not affected by transcription or translation 
inhibitors. Thyroid hormone binds to the binding elements such as integrin $\alpha v \beta 3$ located at the plasma membrane or within a cell to exert its effects. These non-gemonic effects include the regulation of ion influxes, kinase signaling pathways, amino acid accumulation, extracellular nucleotide levels, and vimentin phosphorylation via non-receptor protein kinases downstream (10). While T4 is a pro-hormone, it can bind to TRs but with low affinity, and the T4 liganded-TR is less stable versus the T3-liganded-TR. Nonetheless, T4 serves as an agonist to TRs at appropriate concentration (22), which also depends on receptor isoform and the presence of cellular cofactors (e.g., thyroid hormone receptor-associated protein 220, TRAP200) (23). In addition to the genomic pathway, T4 also initiates rapid non-genomic response by binding to integrin $\alpha \mathrm{v} \beta 3$ in the plasma membrane, leading to an increase in cellular amino acid accumulation (24-26). Collectively, these findings illustrate $\mathrm{T} 4$ has a limited functional role in mammalian cells.

\section{THYROID HORMONE RECEPTORS IN TESTICULAR CELLS}

Thyroid hormone receptors (TRs) are able to mediate the effects of thyroid hormone via classical genomic pathway via two genes, THRA $(\mathrm{TR} \alpha)$ and THRB $(\mathrm{TR} \beta)$. Alternative splicing gives rise to several TR isoforms: $\operatorname{TR} \alpha 1, \alpha 2, \alpha 3$, and $\beta 1, \beta 2, \beta 3$ (21). It is known that $\operatorname{TR} \beta 2$ is restricted to the anterior pituitary and hypothalamus (27), and TR $\beta 3$ is highly expressed in liver, kidney, and lung (28). Although $\mathrm{TR} \alpha 2$ and $\mathrm{TR} \alpha 3$ mRNA are detected in Sertoli cells, these receptors do not have T3-binding capacity (2, 29-31). But they may exert dominant negative effects by binding to TRE to suppress gene transcription $(32,33)$. More important, TR $\alpha 1$ and TR $\beta 1$ are the functional TR isoforms by mediating T3 signaling, and also T4 but to a lesser extent. Both TR $\alpha 1$ and TR $\beta 1$ were shown to be expressed by Sertoli and germ cells throughout development in the rat testis (1). These two TR isoforms are abundantly expressed in neonatal Sertoli cells, suggesting that Sertoli cells might be the target cell type for T3 in the developing testis. A study using TR $\alpha \mathrm{KO}$ or TR $\beta \mathrm{KO}$ mice has demonstrated that TR $\alpha 1$ is the crucial TR isoform, which mediates T3 effects in neonatal Sertoli cells (34). In fact, $\operatorname{TR} \alpha$ serves as a reliable marker of Sertoli cell maturity. Persistent expression of $\operatorname{TR} \alpha$ in adult testes is a reliable indicator of undifferentiated Sertoli cells, such as in neonatal mice $(4,35,36)$ and in mice following deletion of A-kinase anchoring protein 9 (AKAP9) that impedes Sertoli cell differentiation (37). Recently, a transgenic model in which mice expressed a dominant negative TR $\alpha 1$ only in Sertoli cells was generated. By using TR $\alpha^{\mathrm{AMI}}$-SC mice, T3 was shown to be a potent regulator to arrest Sertoli cell mitotic proliferation, which is mediated by an activation of $\mathrm{TR} \alpha 1$ via the $\mathrm{Cdk} / \mathrm{JunD} / \mathrm{c}$-myc pathway (38). This finding is consistent with earlier reports that neonatal hypothyroidism induced in mice or rats by neonatal treatment with a goitrogen leads to an increase in Sertoli cell number and daily sperm production, concomitant with an increase in testis weight, due to a failure of Sertoli cell differentiation, making them mitotically active $(4,36,39,40)$. Also, in rodents when Sertoli cells cease to divide at age $\sim 15$ - to 17 -day postpartum (dpp) to become fully differentiated, this event coincides with a surge in $\mathrm{T} 3$ that peaks in the systemic circulation (41), illustrating a reciprocal relationship between T3 and Sertoli cell mitotic activity and differentiation status. Collectively, these findings illustrate T3 is a regulator of Sertoli cell mitotic function and differentiation status in the testis. Furthermore, TRs are detected in germ cells by immunohistochemistry (1). For instance, TR $\alpha 1$ is expressed by spermatogenic cells from intermediate spermatogonia to midcycle pachytene spermatocytes (1), suggesting that T3 may also play a role in germ cell meiotic development. Additionally, TRs are also expressed by Leydig cells in the interstitial compartment of immature testes (1). In fact, it was reported that Leydig cell differentiation and steroidogenesis in postnatal rat testes were affected by T3 (42).

\section{IODOTHYRONINE DEIODINASES IN TESTIS}

T4 released by the thyroid gland is the pro-hormone, which is converted to bioactive T3 by deiodination of T4 catalyzed by type 1 and type 2 deiodinase (D1 and D2; deiodinase is also known as iodide peroxidase), usually takes place in the liver and kidney (43) (Figure 1). Both the active hormone T3 and pro-hormone T4, however, can also be inactivated via deiodination by type 3 deiodinase (D3), converting into biologically inactive metabolites $3,3^{\prime}$-diiodothyronine (T2) and 3,3',5'-tri-iodothyronine (reverse T3 or rT3) $(43,44)$, respectively (Figure 1). Thus, unlike D1 and D2 that activates thyroid hormones, D3 is an inactivator of thyroid hormones, serving as a modulator of intracellular thyroid hormone levels and action. All three deiodinases are detected in developing and adult testes (45). In developing testis, D3 is the predominant deiodinase and then its activity declines in adult testes (45), whereas D2 is the predominant activating deiodinase in the testis (42). D2 is abundantly expressed in elongated spermatids, whereas its expression could not be detected in Sertoli cells or other germ cells, suggesting that thyroid hormones might play a role in regulating spermatogenesis, specifically on spermiogenesis (9). However, the precise cellular localizations of D1 and D3 in the testis remain unclear. Earlier study has demonstrated that severe hypothyroidism may affect fertility in both sexes (46). Unexpectedly, mice lack either D1, D2 or both D1 and D2 are fertile and display normal serum T3 level (47-49). These findings indicate that in mice, D1 or D2 is not indispensable for maintaining serum T3 level, and D1 or D2-mediated local production of T3 is not likely to be the only source of T3 in the testis. Interestingly, knockout $(\mathrm{KO})$ of $\mathrm{D} 3$ cause impaired fertility in mice, suggesting that D3 may play a more important physiological role in the testis (50). Thus, further studies are necessary to investigate the precise role of deiodinases in the testis.

\section{THYROID HORMONE TRANSPORTERS IN TESTICULAR CELLS}

Since TRs and deiodinases are located intracellularly in mammalian tissues including the seminiferous epithelium in testes, thyroid hormones have to be transported across cell membranes before they can be activated by deiodinases, such as from T4 to T3, to mediate the effects via TRs or be inactivated, such as from T3 to $\mathrm{T} 2$ or T4 to rT3. While there is no specific membrane bound TRs, several membrane bound drug transporters are putative transporters of thyroid hormones that include monocarboxylate transporter (MCT) 8, MCT10, and organic anion-transporting polypeptides (OATPs) $(51,52)$. MCT8 is a specific thyroid hormone transporter. Unlike MCT8, MCT10 not only transports thyroid hormones but also aromatic amino acid. Both of MCTs 


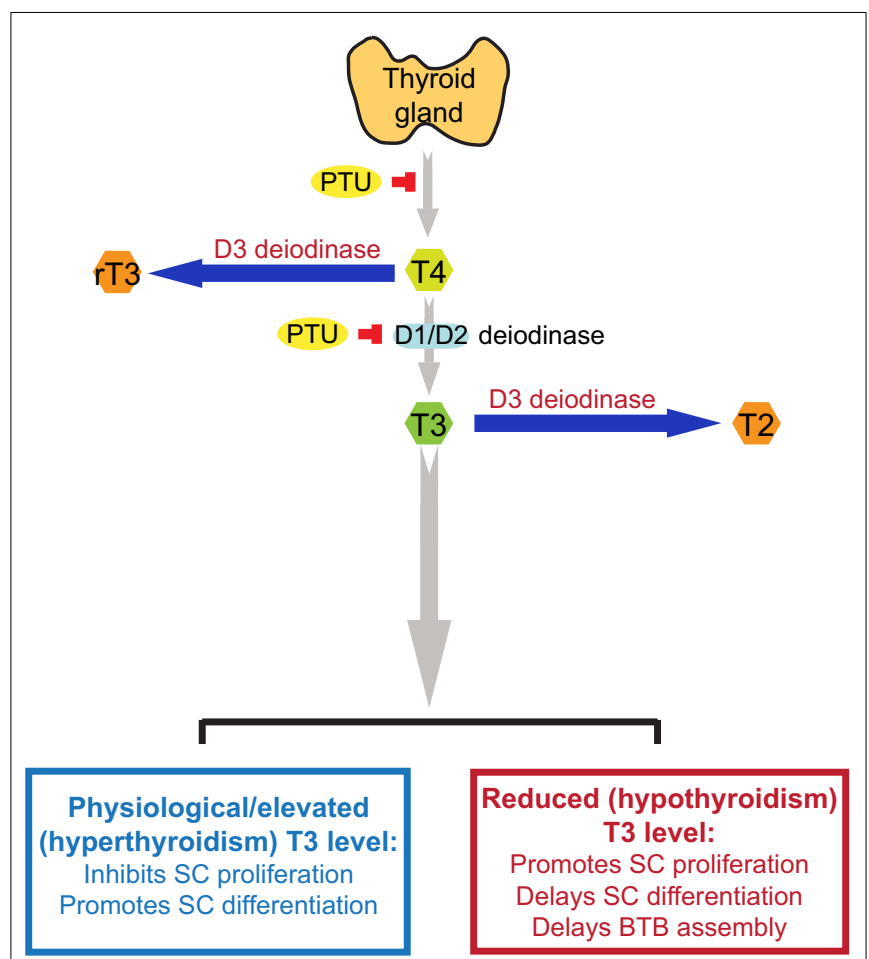

FIGURE 1 | A schematic drawing to illustrate the physiological role of thyroid hormone T3 on testis function. This schematic drawing was prepared based on findings in the literature as discussed herein (see text for details). In short, T4 is the principal thyroid hormone produced by the thyroid gland and released into the systemic circulation. $\mathrm{T4}$, however, is a pro-hormone, which is being activated via the action of deiodinases D1 or D2, mostly in the liver and kidney but also the testis, to form T3, the activated thyroid hormone. However, D1, D2, and D3 deiodinases are also found in the testis. The use of goitrogen [e.g., propylthiouracil (PTU)] can block the production of T4 by thyroid gland, which was used to examine the effects of thyroid hormones on testicular function. D3 deiodinase, unlike $\mathrm{D} 1$ and $\mathrm{D} 2$ deiodinases that activates $\mathrm{T} 4$ to $\mathrm{T} 3$, de-activates $\mathrm{T} 4$ or $\mathrm{T} 3$ to $\mathrm{rT} 3$ or $\mathrm{T} 2$, respectively, which are inactivated thyroid hormones, providing a crucial mechanism to regulate intracellular thyroid hormone action in cells, such as in Sertoli and/or germ cells in the testis. It is known that high level of T3 inhibits Sertoli cell proliferation and promotes Sertoli cell differentiation, whereas low level of T3 causes delayed Sertoli cell proliferation and differentiation. It is noted that at puberty ( $\sim 12$ years of age) in men or by day $\sim 15-17$ day in rodents, there is a surge in T3 level in systemic circulation, coinciding with Sertoli cel differentiation when Sertoli cells cease to divide (see text for details). T4, 3,5,3', 5'-tetraiodothyronine; T3, 3,5,3'-tri-iodothyronine; rT3, 3,3', 5'-tri-iodothyronine; T2, 3,3'-diiodothyronine; PTU, propylthiouracil; SC, Sertoli cell; BTB, blood-testis barrier.

prefer T3 over T4, and MCT10 is even more efficient than MCT8 in transporting T3 across plasma membranes (53). However, studies have shown that MCT8 KO, MCT10 KO, and MCT8/MCT10 double $\mathrm{KO}$ mice are all fertile in both sexes, supporting the notion that other thyroid hormone transporters may compensate the loss of MCT8 and MCT10 (54). Additionally, OATPs are able to transport steroid conjugates, prostaglandins, bile acids, drugs, and thyroid hormones (55). Several OATP family members have been detected in the testis (56). For instance, OATP-F, a homolog of OATP1C1, displaying high affinity for $\mathrm{T} 4$ and $\mathrm{rT} 3$, has been detected in human
Leydig cells (57). OATP6A1, originally identified as a cancer/testis antigen also called SLCO6A1, is predominantly expressed in normal testes (58). In addition, two spliced variants of OATP3A1 called OATP3A1-V1 and OATP3A1-V2 have also been detected in germ cells and Sertoli cells, respectively (59). The rat gonadspecific transporter (GST)-1 and GST-2, which are members of OATPs family are highly expressed in Sertoli cells, spermatogonia, and Leydig cells (60), which may also be involved in T3 and T4 transport across the plasma membrane. A recent study has demonstrated that MCT8 and OATP1C1 are crucial to maintain the thyroid hormone homeostasis in the mouse brain (61), and OATP14 is a high affinity transporter for T4 at the blood-brain barrier (62). Much research is needed to delineate the physiological role of OATPs and MCTs in regulating thyroid hormone transport across the BTB.

\section{EFFECTS OF THYROID HORMONES ON SERTOLI CELL PROLIFERATION, DIFFERENTIATION, AND BTB ASSEMBLY}

Propylthiouracil is a goitrogen that inhibits the enzyme thyroperoxidase by blocking the production of $\mathrm{T} 4$ from thyroglobulin in the thyroid, causing hypothyroidism. It also inhibits $5^{\prime}$-deiodinase that converts T4 to T3. Thus, PTU is a widely used thiouracil-derived drug used to treat hyperthyroidism $(63,64)$. PTU-induced neonatal hypothyroidism by treating neonatal rats from birth was shown to increase rat testis weight and daily sperm production of up to 80 and $140 \%$, respectively $(35,36)$. Further studies demonstrated that this was the result of Sertoli cell proliferation and a delay of Sertoli cell maturation (5). Furthermore, the Sertoli cell BTB failed to assemble by $15-25$ dpp even though some tight junction (TJ) structures were detected by electron microscopy at these ages, but extensive network of TJ ultrastructure and basal ectoplasmic specialization (ES) analogous to age-matched control rats was not found in these rats treated with PTU from birth to age $25 \mathrm{dpp}$ (5). Conversely, neonatal hyperthyroidism was found to stimulate Sertoli cell differentiation, rendering Sertoli cells ceased to proliferate by age 12 versus $\sim 15-17 \mathrm{dpp}$ in normal rats, thereby reducing the testis weight in adult animals at age $100 \mathrm{dpp}$ by almost $50 \%$ (3). These findings suggest that thyroid hormone regulates testis development by modulating Sertoli cells mitotic activity, differentiation status, and the BTB assembly. Table $\mathbf{1}$ summarizes some of the known effects of thyroid hormone T3 on Sertoli and Leydig cell function in the testis.

\section{THYROID HORMONES, GAP JUNCTION, AND EPITHELIAL/ENDOTHELIAL BARRIER FUNCTION}

Gap junctions are intercellular channels, which mediate direct communication between neighboring cells. These channels allow passage of ions and small molecules, usually $<1-1.5 \mathrm{kDa}$, and are involved in several physiological processes, such as cell growth, apoptosis, and differentiation (82-85). Connexin 43 (Cx43) is the predominant GJ protein in the testis $(84,86)$, it is expressed by Sertoli cells, germ cells, as well as Leydig cells in the testis and found at the Sertoli cell-cell and Sertoli-germ cell interface $(87,88)$. Although the $\mathrm{Cx} 43$ germ line $\mathrm{KO}$ mice died shortly after birth due to heart defects, deletion of $\mathrm{Cx} 43$ was shown to induce germ cell deficiency in the testis of developing embryo (89). Interestingly, Sertoli cell-specific Cx43 KO (SC-Cx43 KO) 
Table 1 | Effect of thyroid hormone T3 on testes.

\begin{tabular}{lll}
\hline Cell type & Effects: stimulation (+), inhibition (-) & Reference \\
\hline Sertoli cell & Proliferation (-) & $(3,4)$ \\
& Differentiation (+) & $(3,4,39)$ \\
& ABP production (-) & $(65)$ \\
& AR (+) & $(30)$ \\
& Aromatase (-) & $(66,67)$ \\
& Connexin 43 (+) & $(68)$ \\
& ER (-) & $(69)$ \\
& GLUT1 (+) & $(70)$ \\
& IGF-1 (+) & $(71)$ \\
& Inhibin (+) & $(3)$ \\
& Lactate (+) & $(39)$ \\
& NCAM (-) & $(72)$ \\
& Nidogen (+) & $(73)$ \\
& p21 Cip1 (+) & $(74,75)$ \\
& p27Kip1 (+) & $(74,75)$ \\
& Testosterone metabolism aromatization $(-)$ & $(39)$ \\
& Type IV collagen (-) & $(73)$ \\
& Vimentin phosphorylation (+) & $(76)$ \\
& Differentiation (+) & $(77,78)$ \\
Steroidogenesis (+) & $(79)$ \\
StAR protein (+) & $(79-81)$ \\
\hline & & \\
\hline
\end{tabular}

$A B P$, androgen binding protein; $A R$, androgen receptor; $E R$, estrogen receptor; GLUT1, glucose transporter-1; IGF-1, insulin-like growth factor-1; NCAM, neural cell adhesion molecule.

mice have smaller testes, and the seminiferous tubules of these $\mathrm{KO}$ mice contain mitotically active Sertoli cells and early spermatogonia but not any other germ cell types since spermatogonia failed to differentiate into spermatocytes beyond type A to enter meiosis (90). It is noteworthy that Sertoli cells of SC-Cx43 KO mice remained proliferative in adult mutant mice $(16,90)$, analogous to the phenotypes of Sertoli cells in the goitrogen-induced hypothyroidism model. These findings also illustrate that Sertoli cell maturation is perturbed following deletion of $\mathrm{Cx} 43$ in these mutant mice. TR $\alpha 1$ mRNA expression was also found to be upregulated by 20 - and $60-\mathrm{dpp}$ in the testis of $\mathrm{SC}-\mathrm{Cx} 43 \mathrm{KO}$ mice versus the age-matched control (16). It is noted that $\mathrm{TR} \alpha 1$ is abundantly expressed in the testis during neonatal period but rapidly declines in adulthood in normal rats (21). These findings thus illustrate an inactivation/deletion of $\mathrm{Cx} 43$ causes an upregulation of TR $\alpha 1$, which may mediate thyroid hormone action on Sertoli cell differentiation. Taken collectively, these data thus demonstrate unequivocally that $\mathrm{Cx} 43$ plays a crucial role in spermatogenesis and testis development, which is also involved in thyroid hormone action in the testis. In fact, studies have shown that thyroid hormone may inhibit Sertoli cell proliferation by up-regulating Cx43 expression $(68,91)$. However, the precise mechanism remains unknown. In tumor cells, overexpression of $\mathrm{Cx} 43$ induces cyclindependent kinase inhibitor (CDKI) p27 Kip1 level (92). Consistent with this finding, in vitro studies have shown that T3 up-regulates $\mathrm{p} 27^{\mathrm{Kip} 1}$ and $\mathrm{p} 21^{\mathrm{Cip} 1}$, which, in turn, may play a role in downregulating Sertoli cell proliferation $(74,75,93)$. It is also likely that thyroid hormone regulates $\mathrm{Cx} 43$ expression, which in turn induces the expression of maturation/differentiation markers p27 ${ }^{\mathrm{Kip} 1}$ and p $21^{\text {Cip1 }}$ via a yet-to-be defined signaling pathway, leading to an arrest of Sertoli cell proliferation. This possibility must be carefully evaluated in future studies to define the physiological relationship between $\mathrm{Cx} 43$ and thyroid hormone action in the testis as well as the involving signaling molecules.

While studies using goitrogen and Sertoli cell-specific Cx43 KO models have demonstrated the physiological relationship between thyroid hormone action, Cx43-based GJ function and spermatogenesis (e.g., differentiation of spermatogonia to spermatocytes and the onset of meiosis), in particular, the impact of T3 on Sertoli cell BTB assembly, the molecular mechanism(s) underlying these observations remain unknown. An early report has demonstrated that treatment of chick with thiouracil that inhibits T3 production also delays the development of interdigitation of the lateral plasma membrane between adjacent corneal endothelial cells whereas thyroxine treatment accelerates development of endothelial cell lateral borders (94). These findings are physiologically important to studies in the testis since Sertoli cell cytoplasmic processes create interdigital association with different germ cell types at a Sertoli:germ cell ratio of $\sim 1: 30-1: 50$ during spermatogenesis, requiring extensive interactions between Sertoli and germ cells at the plasma membranes, supporting the notion that T3 may play a role in junction dynamics in the seminiferous epithelium. It is likely that T3-mediated Cx43-based GJ function may be crucial to these events. It is logical to use the goitrogen-induced hypothyroidism model in both neonatal and adult rats to examine changes in junction dynamics at the BTB and also Sertoli-germ cell interface during spermatogenesis in future studies.

\section{CONCLUDING REMARIS AND FUTURE PERSPECTIVES}

Herein, we provide an update on the role of T3 on Sertoli cell maturation, differentiation and BTB assembly during development. Figure 1 summarizes the latest findings regarding the role of thyroid hormones in Sertoli cell proliferation, differentiation, and BTB assembly based on several reports in the last two decades investigating the role of thyroid hormones on testis function. However, there is a lack of data regarding the mechanism(s) by which T3 affects BTB developing at $~ 15-$ to 21-dpp in rats. Does this involve changes in the spatiotemporal expression, localization, and/or intrinsic activity of actin regulatory proteins, such as Arp2/3 (actin-related protein 2/3) complex (a branched actin polymerization inducing protein), palladin (an actin bundling/crosslinking protein), Eps8 (epidermal growth factor receptor pathway substrate 8 , an actin barbed end capping, and bundling protein), which affect organization of actin microfilaments at the BTB? Does this involve changes in the endocytic vesicle-mediated protein trafficking, thereby impeding localization of adhesion protein complexes at the Sertoli cell-cell interface? What is the effect on the actin microfilament organization at the ectoplasmic specialization following knockdown of D1, D2, and/or D3 in Sertoli cells? Many of these questions will need to be addressed before we can gain some insightful information on the role of thyroid hormone on junction dynamics in the testis. Furthermore, selenium, a key element to maintain spermatogenesis and male fertility (95), is the prosthetic group of deiodinases, as such selenocysteine that plays 
an important role in determining the free circulating level of T3 in the mammalian body. As such, the involvement of selenium in thyroid hormone action should also be considered in future studies.

\section{ACKNOWLEDGMENTS}

We thank Dr. Dolores Mruk for the helpful critical discussion during the preparation of this manuscript. This work was supported in part by grants from the National Institutes of Health (NICHD, U54 HD029990, Project 5 to C. Yan Cheng; R01 HD056034 to C. Yan Cheng), the Hong Kong Research Grants Council General Research Fund (771513 to Will M. Lee), the National Science Foundation of China (NSFC/RGC Joint Research Scheme N_HKU 717/12 to Will M. Lee), and the Committee on Research and Conference Grants (University of Hong Kong) Seed Funding (to Will M. Lee).

\section{REFERENCES}

1. Buzzard JJ, Morrison JR, O’Bryan MK, Song Q, Wreford NG. Developmental expression of thyroid hormone receptors in the rat testis. Biol Reprod (2000) 62:664-9. doi:10.1095/biolreprod62.3.664

2. Jannini EA, Crescenzi A, Rucci N, Screponi E, Carosa E, de Matteis A, et al. Ontogenetic pattern of thyroid hormone receptor expression in the human testis. J Clin Endocrinol Metab (2000) 85:3453-7. doi:10.1210/jcem.85.9.6803

3. van Haaster LH, de Jong FH, Docter R, de Rooij DG. High neonatal triiodothyronine levels reduce the period of Sertoli cell proliferation and accelerate tubular lumen formation in the rat testis, and increase serum inhibin levels. Endocrinology (1993) 133:755-60. doi:10.1210/endo.133.2.8344214

4. Cooke PS, Zhao YD, Bunick D. Triiodothyronine inhibits proliferation and stimulates differentiation of cultured neonatal Sertoli cells: possible mechanism for increased adult testis weight and sperm production induced by neonatal goitrogen treatment. Biol Reprod (1994) 51:1000-5. doi:10.1095/biolreprod51.5.1000

5. De Franca LR, Hess RA, Cooke PS, Russell LD. Neonatal hypothyroidism causes delayed Sertoli cell maturation in rats treated with propylthiouracil: evidence that the Sertoli cell controls testis growth. Anat Rec (1995) 242:57-69. doi:10.1002/ar. 1092420108

6. Mendis-Handagama SM, Siril Ariyaratne HB. Leydig cells, thyroid hormones and steroidogenesis. Indian J Exp Biol (2005) 43:939-62.

7. Wagner MS, Morimoto R, Dora JM, Benneman A, Pavan R, Maia AL. Hypothyroidism induces type 2 iodothyronine deiodinase expression in mouse heart and testis. J Mol Endocrinol (2003) 31:541-50. doi:10.1677/jme.0.0310541

8. Pelletier RM. The blood-testis barrier: the junctional permeability, the proteins and the lipids. Prog Histochem Cytochem (2011) 46:49-127. doi:10.1016/j. proghi.2011.05.001

9. Wajner SM, dos Santos Wagner M, Melo RC, Parreira GG, Chiarini-Garcia H, Bianco AC, et al. Type 2 iodothyronine deiodinase is highly expressed in germ cells of adult rat testis. J Endocrinol (2007) 194:47-54. doi:10.1677/JOE-07-0106

10. Zamoner A, Pessoa-Pureur R, Silva FR. Membrane-initiated actions of thyroid hormones on the male reproductive system. Life Sci (2011) 89:507-14. doi:10.1016/j.lfs.2011.04.006

11. Krassas GE, Pontikides N. Male reproductive function in relation with thyroid alterations. Best Pract Res Clin Endocrinol Metab (2004) 18:183-95. doi:10.1016/j.beem.2004.03.003

12. Meeker JD, Godfrey-Bailey L, Hauser R. Relationships between serum hormone levels and semen quality among men from an infertility clinic. J Androl (2007) 28:397-406. doi:10.2164/jandrol.106.001545

13. Weng Q, Saita E, Watanabe G, Takahashi S, Sedqyar M, Suzuki AK, et al. Effect of methimazole-induced hypothyroidism on adrenal and gonadal functions in male Japanese quail (Coturnix japonica). J Reprod Dev (2007) 53:1335-41. doi:10.1262/jrd.19081

14. Krassas GE, Papadopoulou F, Tziomalos K, Zeginiadou T, Pontikides N. Hypothyroidism has an adverse effect on human spermatogenesis: a prospective, controlled study. Thyroid (2008) 18:1255-9. doi:10.1089/thy.2008.0257

15. Krassas GE, Poppe K, Glinoer D. Thyroid function and human reproductive health. Endocr Rev (2010) 31:702-55. doi:10.1210/er.2009-0041
16. Sridharan S, Simon L, Meling DD, Cyr DG, Gutstein DE, Fishman GI, et al. Proliferation of adult Sertoli cells following conditional knockout of the Gap junctional protein GJA1 (connexin 43) in mice. Biol Reprod (2007) 76:804-12. doi:10.1095/biolreprod.106.059212

17. Tarulli GA, Stanton PG, Meachem SJ. Is the adult Sertoli cell terminally differentiated? Biol Reprod (2012) 87:1-11. doi:10.1095/biolreprod.111.095091

18. Surks MI, Oppenheimer JH. Concentration of L-thyroxine and Ltriiodothyronine specifically bound to nuclear receptors in rat liver and kidney. Quantitative evidence favoring a major role of T3 in thyroid hormone action. J Clin Invest (1977) 60:555-62. doi:10.1172/JCI108807

19. Engler D, Burger AG. The deiodination of the iodothyronines and of their derivatives in man. Endocr Rev (1984) 5:151-84. doi:10.1210/edrv-5-2-151

20. Chopra IJ. An assessment of daily production and significance of thyroidal secretion of 3, 3', 5'-triiodothyronine (reverse T3) in man. J Clin Invest (1976) 58:32-40. doi:10.1172/JCI108456

21. Wagner MS, Wajner SM, Maia AL. Is there a role for thyroid hormone on spermatogenesis? Microsc Res Tech (2009) 72:796-808. doi:10.1002/jemt.20759

22. Sandler B, Webb P, Apriletti JW, Huber BR, Togashi M, Cunha Lima ST, et al. Thyroxine-thyroid hormone receptor interactions. J Biol Chem (2004) 279:55801-8. doi:10.1074/jbc.M410124200

23. Schroeder A, Jimenz R, Young B, Privalsky ML. The ability of thyroid hormone receptors to sense T4 as an agonist depends on receptor isoform and on cellular cofactors. Mol Endocrinol (2014) 28:745-57. doi:10.1210/me.2013-1335

24. Menegaz D, Zamoner A, Royer C, Leite LD, Bortolotto ZA, Silva FR. Rapid responses to thyroxine in the testis: active protein synthesisindependent pathway. Mol Cell Endocrinol (2006) 246:128-34. doi:10.1016/j. mce.2005.11.019

25. Menegaz D, Royer C, Rosso A, Souza AZ, Santos AR, Silva FR. Rapid stimulatory effect of thyroxine on plasma membrane transport systems: calcium uptake and neutral amino acid accumulation in immature rat testis. Int J Biochem Cell Biol (2010) 42:1046-51. doi:10.1016/j.biocel.2010.03.015

26. Zanatta AP, Zanatta L, Goncalves R, Zamoner A, Silva FR. Integrin participates in the effect of thyroxine on plasma membrane in immature rat testis. Biochim Biophys Acta (2013) 1830:2629-37. doi:10.1016/j.bbagen. 2012.10.022

27. Hodin RA, Lazar MA, Wintman BI, Darling DS, Koenig RJ, Larsen PR, et al. Identification of a thyroid hormone receptor that is pituitary-specific. Science (1989) 244:76-9. doi:10.1126/science.2539642

28. Williams GR. Cloning and characterization of two novel thyroid hormone receptor beta isoforms. Mol Cell Biol (2000) 20:8329-42. doi:10.1128/MCB.20.22. 8329-8342.2000

29. Jannini EA, Dolci S, Ulisse S, Nikodem VM. Developmental regulation of the thyroid hormone receptor alpha $1 \mathrm{mRNA}$ expression in the rat testis. Mol Endocrinol (1994) 8:89-96. doi:10.1210/me.8.1.89

30. Arambepola NK, Bunick D, Cooke PS. Thyroid hormone effects on androgen receptor messenger RNA expression in rat Sertoli and peritubular cells. J Endocrinol (1998) 156:43-50. doi:10.1677/joe.0.1560043

31. O'Shea PJ, Williams GR. Insight into the physiological actions of thyroid hormone receptors from genetically modified mice. J Endocrinol (2002) 175:553-70. doi:10.1677/joe.0.1750553

32. Tagami T, Kopp P, Johnson W, Arseven OK, Jameson JL. The thyroid hormone receptor variant alpha2 is a weak antagonist because it is deficient in interactions with nuclear receptor corepressors. Endocrinology (1998) 139:2535-44. doi:10.1210/en.139.5.2535

33. Burgos-Trinidad M, Koenig RJ. Dominant negative activity of thyroid hormone receptor variant alpha2 and interaction with nuclear corepressors. Mol Cell Endocrinol (1999) 149:107-14. doi:10.1016/S0303-7207(98)00253-6

34. Holsberger DR, Kiesewetter SE, Cooke PS. Regulation of neonatal Sertoli cell development by thyroid hormone receptor alpha1. Biol Reprod (2005) 73:396-403. doi:10.1095/biolreprod.105.041426

35. Cooke PS, Meisami E. Early hypothyroidism in rats causes increased adult testis and reproductive organ size but does not change testosterone levels. Endocrinology (1991) 129:237-43. doi:10.1210/endo-129-1-237

36. Cooke PS, Hess RA, Porcelli J, Meisami E. Increased sperm production in adult rats after transient neonatal hypothyroidism. Endocrinology (1991) 129:244-8. doi:10.1210/endo-129-1-244

37. Schimenti KJ, Feuer SK, Griffin LB, Graham NR, Bovet CA, Hartford S, et al. AKAP9 is essential for spermatogenesis and Sertoli cell maturation in mice. Genetics (2013) 194:447-57. doi:10.1534/genetics.113.150789 
38. Fumel B, Guerquin MJ, Livera G, Staub C, Magistrini M, Gauthier C, et al. Thyroid hormone limits postnatal Sertoli cell proliferation in vivo by activation of its alphal isoform receptor (TRalpha1) present in these cells and by regulation of Cdk4/JunD/c-myc mRNA levels in mice. Biol Reprod (2012) 87:16,1-9. doi:10.1095/biolreprod.111.098418

39. Palmero S, Prati M, Bolla F, Fugassa E. Tri-iodothyronine directly affects rat Sertoli cell proliferation and differentiation. J Endocrinol (1995) 145:355-62. doi:10.1677/joe.0.1450355

40. Joyce KL, Porcelli JC, Cooke PS. Neonatal goitrogen treatment increases adult testis size and sperm production in the mouse. J Androl (1993) 14:448-55.

41. Hadj-Sahraoui N, Seugnet I, Ghorbel MT, Demeneix B. Hypothyroidism prolongs mitotic activity in the post-natal mouse brain. Neurosci Lett (2000) 280:79-82. doi:10.1016/S0304-3940(00)00768-0

42. Wagner MS, Wajner SM, Maia AL. The role of thyroid hormone in testicular development and function. J Endocrinol (2008) 199:351-65. doi:10.1677/JOE08-0218

43. Kuiper GG, Kester MH, Peeters RP, Visser TJ. Biochemical mechanisms of thyroid hormone deiodination. Thyroid (2005) 15:787-98. doi:10.1089/thy.2005. 15.787

44. Bianco AC, Salvatore D, Gereben B, Berry MJ, Larsen PR. Biochemistry, cellular and molecular biology, and physiological roles of the iodothyronine selenodeiodinases. Endocr Rev (2002) 23:38-89. doi:10.1210/edrv.23.1.0455

45. Bates JM, St Germain DL, Galton VA. Expression profiles of the three iodothyronine deiodinases, D1, D2, and D3, in the developing rat. Endocrinology (1999) 140:844-51. doi:10.1210/en.140.2.844

46. Beamer WJ, Eicher EM, Maltais LJ, Southard JL. Inherited primary hypothyroidism in mice. Science (1981) 212:61-3. doi:10.1126/science.7209519

47. Schneider MJ, Fiering SN, Pallud SE, Parlow AF, St Germain DL, Galton VA. Targeted disruption of the type 2 selenodeiodinase gene (DIO2) results in a phenotype of pituitary resistance to T4. Mol Endocrinol (2001) 15:2137-48. doi:10.1210/mend.15.12.0740

48. Schneider MJ, Fiering SN, Thai B, Wu SY, St Germain E, Parlow AF, et al. Targeted disruption of the type 1 selenodeiodinase gene (Diol) results in marked changes in thyroid hormone economy in mice. Endocrinology (2006) 147:580-9. doi:10.1210/en.2005-0739

49. Galton VA, Schneider MJ, Clark AS, St Germain DL. Life without thyroxine to 3,5,3'-triiodothyronine conversion: studies in mice devoid of the 5'-deiodinases. Endocrinology (2009) 150:2957-63. doi:10.1210/en.2008-1572

50. Hernandez A, Martinez ME, Fiering S, Galton VA, St Germain D. Type 3 deiodinase is critical for the maturation and function of the thyroid axis. J Clin Invest (2006) 116:476-84. doi:10.1172/JCI26240

51. Visser WE, Friesema EC, Jansen J, Visser TJ. Thyroid hormone transport in and out of cells. Trends Endocrinol Metab (2008) 19:50-6. doi:10.1016/j.tem.2007. 11.003

52. Hagenbuch B. Cellular entry of thyroid hormones by organic anion transporting polypeptides. Best Pract Res Clin Endocrinol Metab (2007) 21:209-21. doi:10.1016/j.beem.2007.03.004

53. Visser WE, Friesema EC, Jansen J, Visser TJ. Thyroid hormone transport by monocarboxylate transporters. Best Pract Res Clin Endocrinol Metab (2007) 21:223-36. doi:10.1016/j.beem.2007.03.008

54. Muller J, Mayerl S, Visser TJ, Darras VM, Boelen A, Frappart L, et al. Tissue-specific alterations in thyroid hormone homeostasis in combined Mct10 and Mct8 deficiency. Endocrinology (2014) 155:315-25. doi:10.1210/en.20131800

55. Hagenbuch B, Gui C. Xenobiotic transporters of the human organic anion transporting polypeptides (OATP) family. Xenobiotica (2008) 38:778-801. doi:10.1080/00498250801986951

56. Su L, Mruk DD, Cheng CY. Drug transporters, the blood-testis barrier and spermatogenesis. J Endocrinol (2011) 208:207-23. doi:10.1677/JOE-10-0363

57. Pizzagalli F, Hagenbuch B, Stieger B, Klenk U, Folkers G, Meier PJ. Identification of a novel human organic anion transporting polypeptide as a high affinity thyroxine transporter. Mol Endocrinol (2002) 16:2283-96. doi:10.1210/me.20010309

58. Lee SY, Williamson B, Caballero OL, Chen YT, Scanlan MJ, Ritter G, et al. Identification of the gonad-specific anion transporter SLCO6Al as a cancer/testis (CT) antigen expressed in human lung cancer. Cancer Immun (2004) 4:13
59. Huber RD, Gao B, Sidler Pfandler MA, Zhang-Fu W, Leuthold S, Hagenbuch $\mathrm{B}$, et al. Characterization of two splice variants of human organic anion transporting polypeptide 3A1 isolated from human brain. Am J Physiol Cell Physiol (2007) 292:C795-806. doi:10.1152/ajpcell.00597.2005

60. Suzuki T, Onogawa T, Asano N, Mizutamari H, Mikkaichi T, Tanemoto M, et al. Identification and characterization of novel rat and human gonad-specific organic anion transporters. Mol Endocrinol (2003) 17:1203-15. doi:10.1210/me. 2002-0304

61. Mayerl S, Muller J, Bauer R, Richert S, Kassmann CM, Darras VM, et al. Transporters MCT8 and OATP1C1 maintain murine brain thyroid hormone homeostasis. J Clin Invest (2014) 124:1987-99. doi:10.1172/JCI70324

62. Sugiyama D, Kusuhara H, Taniguchi H, Ishikawa S, Nozaki Y, Aburatani H, et al. Functional characterization of rat brain-specific organic anion transporter (Oatp14) at the blood-brain barrier: high affinity transporter for thyroxine. J Biol Chem (2003) 278:43489-95. doi:10.1074/jbc.M306933200

63. Weissel M. Propylthiouracil: clinical overview of its efficacy and its side effects more than 50 years after the introduction of its use in thyrostatic treatment. Exp Clin Endocrinol Diabetes (2010) 118:101-4. doi:10.1055/s-0029-1215587

64. Glinoer D, Cooper DS. The propylthiouracil dilemma. Curr Opin Endocrinol Diabetes Obes (2012) 19:402-7. doi:10.1097/MED.0b013e3283565b49

65. Fugassa E, Palmero S, Gallo G. Triiodothyronine decreases the production of androgen binding protein by rat Sertoli cells. Biochem Biophys Res Commun (1987) 143:241-7. doi:10.1016/0006-291X(87)90656-5

66. Ando S, Sirianni R, Forastieri P, Casaburi I, Lanzino M, Rago V, et al. Aromatase expression in prepuberal Sertoli cells: effect of thyroid hormone. Mol Cell Endocrinol (2001) 178:11-21. doi:10.1016/S0303-7207(01)00443-9

67. Catalano S, Pezzi V, Chimento A, Giordano C, Carpino A, Young M, et al. Triiodothyronine decreases the activity of the proximal promoter (PII) of the aromatase gene in the mouse Sertoli cell line, TM4. Mol Endocrinol (2003) 17:923-34. doi:10.1210/me.2002-0102

68. Gilleron J, Nebout M, Scarabelli L, Senegas-Balas F, Palmero S, Segretain D, et al. A potential novel mechanism involving connexin 43 gap junction for control of Sertoli cell proliferation by thyroid hormones. J Cell Physiol (2006) 209:153-61. doi: $10.1002 /$ jcp. 20716

69. Sisci D, Panno ML, Salerno M, Maggiolini M, Pezzi V, Morrone EG, et al. A time course study on the "in vitro" effects of T3 and testosterone on androgen and estrogen receptors in peripuberal primary rat Sertoli cells. Exp Clin Endocrinol Diabetes (1997) 105:218-24. doi:10.1055/s-0029-1211755

70. Ulisse S, Jannini EA, Pepe M, De Matteis S, D'Armiento M. Thyroid hormone stimulates glucose transport and GLUT1 mRNA in rat Sertoli cells. Mol Cell Endocrinol (1992) 87:131-7. doi:10.1016/0303-7207(92)90241-W

71. Palmero S, Prati M, Barreca A, Minuto F, Giordano G, Fugassa E. Thyroid hormone stimulates the production of insulin-like growth factor I (IGF-I) by immature rat Sertoli cells. Mol Cell Endocrinol (1990) 68:61-5. doi:10.1016/03037207(90)90170-D

72. Laslett AL, Li LH, Jester WF Jr, Orth JM. Thyroid hormone down-regulates neural cell adhesion molecule expression and affects attachment of gonocytes in Sertoli cell-gonocyte cocultures. Endocrinology (2000) 141:1633-41. doi:10.1210/en.141.5.1633

73. Ulisse S, Rucci N, Piersanti D, Carosa E, Graziano FM, Pavan A, et al. Regulation by thyroid hormone of the expression of basement membrane components in rat prepubertal Sertoli cells. Endocrinology (1998) 139:741-7. doi:10.1210/endo.139.2.5732

74. Buzzard JJ, Wreford NG, Morrison JR. Thyroid hormone, retinoic acid, and testosterone suppress proliferation and induce markers of differentiation in cultured rat Sertoli cells. Endocrinology (2003) 144:3722-31. doi:10.1210/en.20030379

75. Holsberger DR, Jirawatnotai S, Kiyokawa H, Cooke PS. Thyroid hormone regulates the cell cycle inhibitor p27Kip1 in postnatal murine Sertoli cells. Endocrinology (2003) 144:3732-8. doi:10.1210/en.2003-0389

76. Zamoner A, Corbelini PF, Funchal C, Menegaz D, Silva FR, Pessoa-Pureur R. Involvement of calcium-dependent mechanisms in T3-induced phosphorylation of vimentin of immature rat testis. Life Sci (2005) 77:3321-35 doi:10.1016/j.lfs.2005.05.042

77. Teerds KJ, de Rooij DG, de Jong FH, van Haaster LH. Development of the adulttype Leydig cell population in the rat is affected by neonatal thyroid hormone levels. Biol Reprod (1998) 59:344-50. doi:10.1095/biolreprod59.2.344 
78. Ariyaratne HB, Mendis-Handagama SM, Mason JI. Effects of tri-iodothyronine on testicular interstitial cells and androgen secretory capacity of the prepubertal Rat. Biol Reprod (2000) 63:493-502.

79. Manna PR, Tena-Sempere M, Huhtaniemi IT. Molecular mechanisms of thyroid hormone-stimulated steroidogenesis in mouse Leydig tumor cells. Involvement of the steroidogenic acute regulatory (StAR) protein. J Biol Chem (1999) 274:5909-18. doi:10.1074/jbc.274.9.5909

80. Manna PR, Kero J, Tena-Sempere M, Pakarinen P, Stocco DM, Huhtaniemi IT. Assessment of mechanisms of thyroid hormone action in mouse Leydig cells: regulation of the steroidogenic acute regulatory protein, steroidogenesis, and luteinizing hormone receptor function. Endocrinology (2001) 142:319-31. doi:10.1210/endo.142.1.7900

81. Manna PR, Roy P, Clark BJ, Stocco DM, Huhtaniemi IT. Interaction of thyroid hormone and steroidogenic acute regulatory (StAR) protein in the regulation of murine Leydig cell steroidogenesis. JSteroid Biochem Mol Biol (2001) 76:167-77. doi:10.1016/S0960-0760(00)00156-4

82. Sridharan S, Brehm R, Bergmann M, Cooke PS. Role of connexin 43 in Sertoli cells of testis. Ann NY Acad Sci (2007) 1120:131-43. doi:10.1196/annals. 1411.004

83. Pointis G, Gilleron J, Carette D, Segretain D. Physiological and physiopathological aspects of connexins and communicating gap junctions in spermatogenesis. Philos Trans R Soc Lond B Biol Sci (2010) 365:1607-20. doi:10.1098/rstb.2009. 0114

84. Pointis G, Gilleron J, Carette D, Segretain D. Testicular connexin 43, a precocious molecular target for the effect of environmental toxicants on male fertility Spermatogenesis (2011) 1:303-17. doi:10.4161/spmg.1.4.18392

85. Li MW, Mruk DD, Cheng CY. Gap junctions and blood-tissue barriers. Adv Exp Med Biol (2012) 763:260-80.

86. Batias C, Defamie N, Lablack A, Thepot D, Fenichel P, Segretain D, et al. Modified expression of testicular gap-junction connexin 43 during normal spermatogenic cycle and in altered spermatogenesis. Cell Tissue Res (1999) 298:113-21. doi:10.1007/s004419900076

87. Tan IP, Roy C, Saez JC, Saez CG, Paul DL, Risley MS. Regulated assembly of connexin33 and connexin43 into rat Sertoli cell gap junctions. Biol Reprod (1996) 54:1300-10. doi:10.1095/biolreprod54.6.1300

88. Li MWM, Mruk DD, Lee WM, Cheng CY. Connexin 43 and plakophilin-2 as a protein complex that regulates blood-testis barrier dynamics. Proc Natl Acad Sci U S A (2009) 106:10213-8. doi:10.1073/pnas.0901700106

89. Juneja SC, Barr KJ, Enders GC, Kidder GM. Defects in the germ line and gonads of mice lacking connexin43. Biol Reprod (1999) 60:1263-70. doi:10. 1095/biolreprod60.5.1263
90. Brehm R, Zeiler M, Ruttinger C, Herde K, Kibschull M, Winterhager E, et al. A Sertoli cell-specific knockout of connexin43 prevents initiation of spermatogenesis. Am J Pathol (2007) 171:19-31. doi:10.2353/ajpath.2007.061171

91. St-Pierre N, Dufresne J, Rooney AA, Cyr DG. Neonatal hypothyroidism alters the localization of gap junctional protein connexin 43 in the testis and messenger RNA levels in the epididymis of the rat. Biol Reprod (2003) 68:1232-40. doi:10.1095/biolreprod.102.010504

92. Koffler L, Roshong S, Kyu Park I, Cesen-Cummings K, Thompson DC, DwyerNield LD, et al. Growth inhibition in $\mathrm{G}(1)$ and altered expression of cyclin D1 and p27(kip-1)after forced connexin expression in lung and liver carcinoma cells. J Cell Biochem (2000) 79:347-54. doi:10.1002/1097-4644(20001201)79: $3<347:$ :AID-JCB10>3.0.CO;2-2

93. Holsberger DR, Buchold GM, Leal MC, Kiesewetter SE, O’Brien DA, Hess RA, et al. Cell-cycle inhibitors p27Kip1 and p21Cip1 regulate murine Sertoli cell proliferation. Biol Reprod (2005) 72:1429-36. doi:10.1095/biolreprod.105. 040386

94. Masterson E, Edelhauser HF, Van Horn DL. The role of thyroid hormone in the development of the chick corneal endothelium and epithelium. Invest Ophthalmol Vis Sci (1977) 16:105-15.

95. Boitani C, Puglisi R. Selenium, a key element in spermatogenesis and male fertility. Adv Exp Med Biol (2008) 636:65-73. doi:10.1007/978-0-38709597-4_4

Conflict of Interest Statement: The authors declare that the research was conducted in the absence of any commercial or financial relationships that could be construed as a potential conflict of interest.

Received: 15 September 2014; accepted: 14 October 2014; published online: 05 November 2014.

Citation: Gao Y, Lee WM and Cheng CY (2014) Thyroid hormone function in the rat testis. Front. Endocrinol. 5:188. doi: 10.3389/fendo.2014.00188

This article was submitted to Experimental Endocrinology, a section of the journal Frontiers in Endocrinology.

Copyright $(2) 2014$ Gao, Lee and Cheng. This is an open-access article distributed under the terms of the Creative Commons Attribution License (CC BY). The use, distribution or reproduction in other forums is permitted, provided the original author (s) or licensor are credited and that the original publication in this journal is cited, in accordance with accepted academic practice. No use, distribution or reproduction is permitted which does not comply with these terms. 